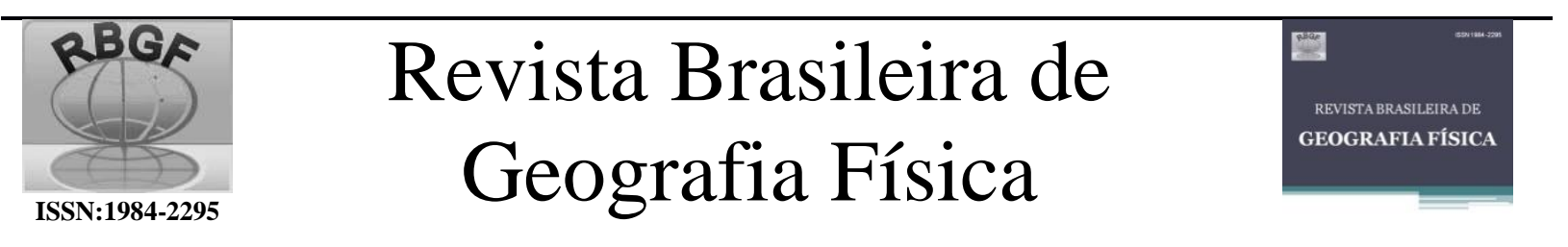

Homepage: www.ufpe.br/rbgfe

\title{
A multivariate assessment of soil contamination by arsenic in the urban area of Ouro Preto,
} Brasil

José Augusto Costa Gonçalves ${ }^{1}$ (autor correspondente); (jaucosta@ unifei.edu.br), Diego Lang Burak ${ }^{2}$, Jorge Carvalho de Lena $^{3}$, Eliane Maria Vieira ${ }^{4}$, Roberto Cezar Almeida Monte - Mor ${ }^{5}$, Giselle de Paula Queiroz Cunha ${ }^{6}$, James Lacerda Maia $^{7}$, Rose Marie Belardi ${ }^{8}$ 1,4,5,6,7,8 Professor Adjunto da Universidade Federal de Itajubá - UNIFEI/Itabira - MG, ${ }^{2}$ Professor Adjunto da Universidade Federal do Espírito Santo - UFES - ES, ${ }^{3}$ Professor Associado da Universidade Federal de Ouro Preto - UFOP - MG

Artigo recebido em 18/05/2016 e aceito em 01/08/2016

\begin{abstract}
A B S T R A C T
Arsenic (As) is a toxic and carcinogenic element, whose compounds are present in the environment and in biological systems. The most common way of human exposure to As is through consumption of contaminated water, inhalation of gases and ingestion of dust derived from soil. Contamination by As affects millions of people yearly throughout the planet. In the city of Ouro Preto, Brazil, in the neighborhoods of Piedade, Antônio Dias, Padre Faria, Taquaral and Alto da Cruz, 21 soil samples were collected in a $2 \mathrm{~km}^{2}$ area for the purpose of analyzing their physical properties, chemical composition, mineralogy and the presence of As. Of all samples, 15 presented a predominantly clay texture and 12 of them presented As contents higher than $250 \mathrm{mg} \cdot \mathrm{kg}^{-1}$. In general, the As contents varied from 6 to $925 \mathrm{mg} \cdot \mathrm{kg}^{-1}$. Primary or secondary As minerals were not found, which suggests their retention and adsorption by the oxides and hydroxides of $\mathrm{Fe}, \mathrm{Al}$ and clay minerals. The main minerals found were quartz, muscovite, kaolinite, goethite, hematite, illite and gibbsite. Multivariate techniques (HCA and FA) were applied to assess the spatial distribution of As and its associations. Results show that As is distributed in the North of the studied region, strongly linked to clay fraction, which, in turn, is characterized by the presence of goethite and talc, which are the carriers of As.

Keywords: Arsenic, Contaminated Soil, Ouro Preto, Iron Quadrangle, Multivariate Analysis
\end{abstract}

\section{Introduction}

It is well known that weathering of bedrock and pedogenesis processes forms soils, and their geochemical attributes reflect the characteristics of the parental material. However, the movement and mixture of different land areas as a consequence of human activity impose the introduction of new compounds and new substances on the environment that may affect human beings who have settled over areas covered with these materials. In abandoned mining areas there are tailing piles resulting from extraction processes with characteristics inherent to the ore and the surrounding rock, which are source of chemical elements at a high concentration, and, for that reason, may be a source of dispersion and consequently of environmental contamination, especially of trace elements such as heavy metals and metalloids. The transfer of chemical elements between the various constituent phases of the soil may be considered as the main process in control of their solubility, mobility and availability to surface water and groundwater and to live organisms Kabata-Pendias (2004).

The availability of heavy metals depends on their presence in the soil solution and is governed by the composition and reaction of the system, by oxy-reduction conditions and by reaction kinetics. The tendency for the formation of insoluble compounds also plays an important role, because they coprecipitate with minerals and form complexes with organic matter (Alloway, 1990).

In various parts of the world, studies regarding the natural presence of As in soils or resulting from human activity are reported. In Brazil, Curi \& Franzmeir (1987) found As contents in red ferric latosol from 6 to $10 \mathrm{mg} . \mathrm{kg}-1$, while in ferric latosol the value was $36 \mathrm{mg} \cdot \mathrm{kg}^{-1}$. In the Iron Quadrangle, Matschullat et al. (2000) found As concentrations in soils with values ranging from 200 to $860 \mathrm{mg} \cdot \mathrm{kg}^{-1}$. Andrade et al. (2009) found As contents between 46.5 and $238.7 \mathrm{mg} \cdot \mathrm{kg}^{-1}$ in lithosols and oxisols of the Itacolomi State Park at the Córrego do Manso drainage sub-basin, 
(Ferreira \& Lazarin, 1993). Marques (2000) reported As concentrations around $38 \mathrm{mg} \cdot \mathrm{kg}^{-1}$ in oxisols of the dry savannah, while Licht \& Plawiak (2005), studying 43 soil samples from the state of Paraná, reported average As concentration values of $7.5 \mathrm{mg} \cdot \mathrm{kg}^{-1}$. In the urban area of Ouro Preto, As contents in the soil were found ranging from 6 mg.kg ${ }^{-1}$ to $925 \mathrm{mg} \cdot \mathrm{kg}^{-1}$ (Gonçalves, 2011).

In Brazil, specifically in the region of the Iron Quadrangle, previous studies report contamination of stream sediments, surface waters and groundwater by arsenic. Eleutério (1997) registered arsenic content of $620 \mathrm{mg} \cdot \mathrm{kg}^{-1}$ in the summer and 1,268 mg.kg-1 in the winter in stream sediments of the Carmo River. Mattschullat et al. (2000), investigating the As presence in urine of 7 to 12-year-old children in the counties of Nova Lima and Santa Bárbara, found concentrations from 2 to $106 \mu \mathrm{g} . \mathrm{L}^{-1}, 22 \%$ of the children presented concentrations higher than $40 \mu \mathrm{g} . \mathrm{L}^{-1}$. In Ouro Preto, Pimentel et al. (2003) analyzed waters from abandoned gold mines and springs and reported As contents from 0.07 to $2.30 \mathrm{mg} . \mathrm{L}^{-1}$. Borba (2002), in studies undertaken in the auriferous districts located in the drainage basins of the Carmo, Conceição and das Velhas Rivers, found As concentrations in sediments up to 4,000 mg.kg-1 ${ }^{-1}$ In surface waters, the As contents reached $350 \mu \mathrm{g} . \mathrm{L}^{-}$ ${ }^{1}$, while in the groundwater of the Ouro Preto and Mariana, the As concentrations were up to 2,800 $\mu \mathrm{g} . \mathrm{L}^{-1}$. Gonçalves et al. (2007) found As contents in groundwater consumed by the Ouro Preto population of $224 \mu \mathrm{g} \cdot \mathrm{L}^{-1}$.

Mining areas are drastically altered and, in this context, evaluation of soil contamination is the first step toward knowledge of degraded areas. In this context, the objective of this study is the physical, chemical and mineralogical characterization of the soils of five neighborhoods of the city of Ouro Preto, seeking to understand the influence of the bedrock on the origin and on the processes of soil evolution and properties, as well as understanding and evaluating arsenic concentrations in the area.
The study area (Figure 1A) is inserted in the Southeastern part of the Iron Quadrangle region, which encompasses an area of $7,200 \mathrm{~km}^{2}$ located in the south-central part of the state of Minas Gerais, Brazil. The climate of the city of Ouro Preto, according to international classification Koppen (1948), is of the Cwb type (Coelho 1994). According to the IGA (1995), which analyzed the rainfall data provided by the 5th Meteorological District, the average annual rainfall is $1723.6 \mathrm{~mm}$. The rainy season extends from October to March and concentrates $89.6 \%$ of annual rainfall. The average annual temperature is $18.5^{\circ} \mathrm{C}$, with the month of January being the hottest with the maximum annual average temperature of $21.2{ }^{\circ} \mathrm{C}$ and July the coldest, with the minimum annual average temperature of 15.5 ${ }^{\circ} \mathrm{C}$.

The geological constitution of the city of Ouro Preto includes a set of metasedimentary and metavolcanic rocks belonging to the Minas and Rio das Velhas Supergroups. The Minas Supergroup includes a metasedimentary sequence of Paleoproterozoic age and has been divided, from the base to the top, into the Caraça, Itabira and Piracicaba Groups Dorr (1969), Ladeira (1980), Marshak \& Alkmim (1989), Alkmim \& Marshak (1998). The Rio das Velhas Supergroup represents a volcanic-sedimentary sequence of the Greenstone Belt type and has been divided Dorr et al. (1957), from the base to the top, into the Nova Lima and Maquiné Groups. The Nova Lima Group is divided into three units: metavolcanic (basal); chemical metasedimentary (intermediate) and clastic metasedimentary (on the top). The Maquiné Group is divided, from the base to the top, by the Palmital and Casa Forte formations. The stratigraphic section of the study area is formed by the following units, from the base to the top: metapelitic sericitic; quartzitic; metapelitic carbonous, banded iron and dolomitic carbonatic. Such units correspond to the Nova Lima Group, Moeda Formation, Batatal Formation, Cauê Formation and Gandarela Formation, Cercadinho Formation, Sabará Group and Lateritic Cover (Dorr, 1969) respectively. The distribution of these units occurs in continuous layers, presenting vertical variations.

Study Area 

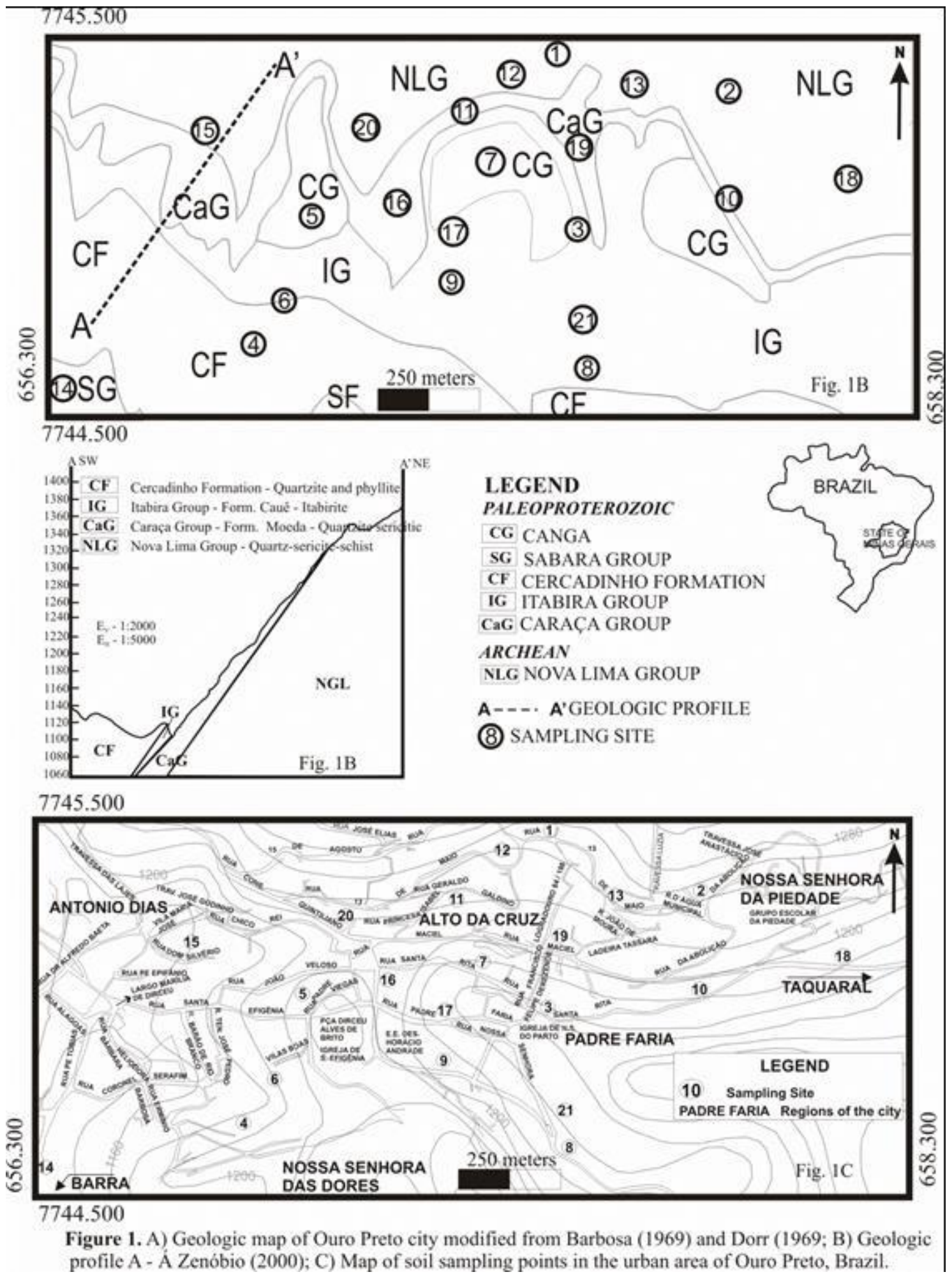

\section{Materials and methods}

Twenty-one soil samples were collected in the urban area of the city of Ouro Preto (Figure 1C), specifically in the neighborhoods of Padre Faria, Piedade, Antônio Dias, Barra, Alto da Cruz and Taquaral. Soil sampling was carried out in regular predetermined intervals, in which the sampling points were arranged as not to be spaced more than 150 meters from each other. UTM coordinates were assigned to each point. Composite samples were comprised of 4 sub-sets taken from the sampling points within a $5 \mathrm{~m}$ diameter circle. Samples $(2.0 \mathrm{~kg})$ were removed with a stainless steel auger to a depth of $10 \mathrm{~cm}$, quartered and, from each quarter, sub aliquots of 
approximately $100 \mathrm{~g}$ were taken. These samples were dried in air; clods were broken up and then passed through a $2 \mathrm{~mm}$ plastic mesh sieve to obtain air-dried samples.

Mineralogical analyses by X-ray diffraction were undertaken using a Rigaku D-Max diffractometer, equipped with a cobalt tube (radiation $\mathrm{Co}-\mathrm{K} \alpha, \lambda=1.79026 \AA$ ), operating with a voltage of $40 \mathrm{kV}$ and a $30 \mathrm{~mA}$ current. The sweep amplitude was undertaken step by step in the interval from 4 to $50^{\circ} 2 \theta$, with an increment of $0.05^{\circ}$ and time of 1 second in each step. Bulk chemical composition was obtained by X-Ray fluorescence spectrometry, using a Panalytical spectrometer model PW2400, Samples $(1,0000 \mathrm{~g})$ were fused with $6 \mathrm{~g}$ of a $1: 1 \quad \mathrm{LiBO}_{2} / \mathrm{Li}_{2} \mathrm{~B}_{4} \mathrm{O}_{7}$ mixture. Arsenic was determined by hydride generation technique using a Varian spectrometer model VGA 76 hydride generator.

For granulometric analyses samples were treated with $\mathrm{NaClO}$ solution for the removal of organic matter and with $\mathrm{NaOH} 0.2$ mol.L $\mathrm{L}^{-1}$ solution for the dispersion of colloidal fractions. For the separation of fractions for mineralogical analyses, the sand fraction was separated with $0.052 \mathrm{~mm}$ sieve and the silt and clay fractions were separated by sedimentation process (Gee \& Bauder, 1986). The sand fraction was cleaned for residual clay fractions by raising the $\mathrm{pH}$ to 10 with $0,1 \mathrm{~g} . \mathrm{L}^{-1}$ $\mathrm{Na}_{2} \mathrm{CO}_{3}$ solution.

Statistical analyses were performed with a Minitab version 14. It consisted of Hierarchical Cluster Analyses and Factor Analyses - R-mode (Manly, 2004), with varimax rotation, aiming to classify the soil samples in order to assess and to relate the As to the rock type.

\section{Results and discussion}

Considering that the study area is totally urbanized, including five neighborhoods of the city of Ouro Preto, observation and access to exposed rock becomes difficult. The outcrop lithologies near the locations where soil samples were collected are (Figure 1C) A1 - Quartzite, ferruginous quartzite, phyllite; A2 - Ferruginous quartzite; A3 - Quartzite, metagreywacke, phyllite; A4 - Canga, quartzite, ferruginous quartzite, phyllite, dolomite, chlorite-schist; A5 - Canga, ferruginous quartzite, conglomerate, phyllite, dolomite, chlorite-schist; A6 - Canga, quartzite, ferruginous quartzite; A7 - Conglomerate, phyllite, dolomite, chlorite-schist.
The mineralogical analysis (Figure2) shows that samples contain kaolinite, illite, goethite and gibbsite as main minerals, in addition to talc, quartz and hematite. Primary minerals which are carriers of As were not identified.

Chemical data (Table 1) were used for a statistical analysis, combining Hierarchical Cluster Analysis (HCA) and Factor Analysis (FA) (Manly, 2004). The first technique classifies samples according to their similarities based on their characteristics. For this specific study the chemical composition was used to calculate Pearson distances and a dendrogram was obtained with single linkage method (Everitt, et al. 2011). The HCA shows that the samples can be divided into two groups (Figure 3). Group A SOL01, SOL16, SOL09, SOL17, SOL21, SOL04, SOL05, SOL08 e SOL06 and group B SOL02, SOL15, SOL18, SOL10, SOL13, SOL12, SOL20, SOL07, SOL03, SOL14, SOL11 e SOL19. Samples of group A are located in the Southern part of the studied area (Figure 1) on Itabira and Cercadinho formations, while samples classified in group B are located in the Nova Lima Group and over Canga. The same set of data was used for the FA study. This technique aims to describe a given number of variables in terms of a smaller set of data or factors, which are orthogonal and hence independent, which can, therefore, be independently analyzed. For our set of data the number of factor extracted was determined by the Principal Component Analysis Method, loadings and communality were maximized by the varimax rotation method.

Soil properties may be explained in term of 3 factors (Table 2). Communalities show that $\mathrm{TiO}_{2}$ and $\mathrm{MnO}$ are not important for the explanation of the variance of data, because of their low values. The first factor (F1) responds for $36.6 \%$ of the variance of the data. The signs of the loadings oppose $\mathrm{SiO}_{2}, \mathrm{Fe}_{2} \mathrm{O}_{3}, \mathrm{P}_{2} \mathrm{O}_{5}$ and As, showing that As is associated to $\mathrm{Fe}$ minerals, mainly goethite. These opposite signs also reflect the composition and distribution of granulometric fractions. $\mathrm{SiO}_{2}$ may represent the sand fraction (coarse and fine), which may be formed mainly by quartz together with other silicate minerals, while $\mathrm{Fe}_{2} \mathrm{O}_{3}$ represents the clay fraction dominated by goethite to which As (and P) are associated, mainly adsorbed. The second factor (F2) responds for $20.4 \%$ of the variance. $\mathrm{Al}_{2} \mathrm{O}_{3}, \mathrm{Na}_{2} \mathrm{O}$ and $\mathrm{K}_{2} \mathrm{O}$ are the elements with highest loading values - all of them with the same sign. 
These elements suggest the presence of feldspar as detritic minerals in the samples, but considering the low content of $\mathrm{Na}_{2} \mathrm{O}$ and $\mathrm{K}_{2} \mathrm{O}$ it is a better choice to assume that this factor reflects the presence of kaolinite, which is the main weathering product of feldspars. Clay fraction is also important in this factor. $\mathrm{Fe}_{2} \mathrm{O}_{3}$ (with a loading value of 0.429 ) could play an important role in the silt fraction. Finally factor 3 (F3) responds for $15.5 \%$ of the variance of the data. $\mathrm{CaO}$ and $\mathrm{MgO}$ have the highest loading values. These elements are ordinarily present in mafic minerals (pyroxenes and amphiboles), $\mathrm{CaO}$ is also present as plagioclases, common minerals in mafic rocks. Therefore this factor may represent the presence of mafic rocks and their weathering products. These factors are independent source of elements to the soil and it is clear that As is associated to goethite, which is a weathering product of mafic minerals.
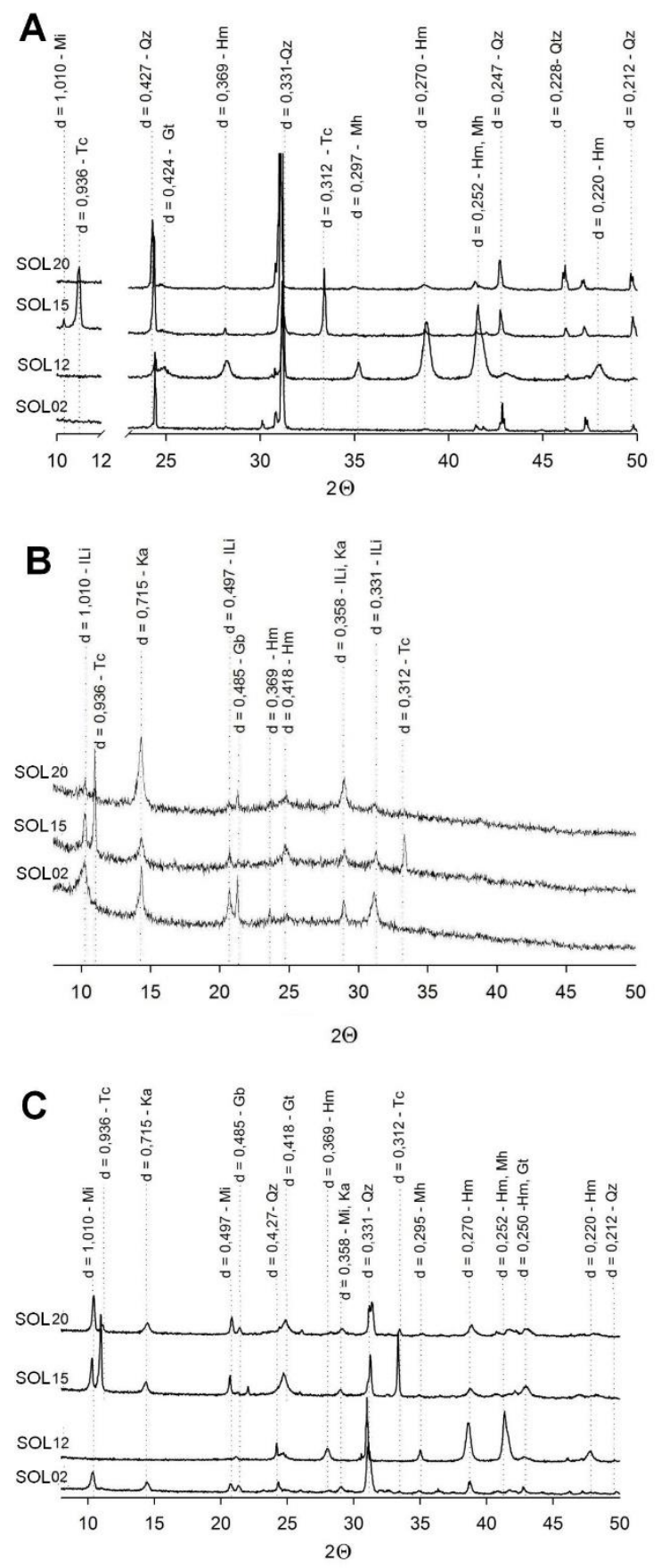

Figure 2 - X-Ray diffraction spectra (diffractogram) of soil samples collected in the city of Ouro Preto, Brazil 
Revista Brasileira de Geografia Física v.09, n.04 (2016) 1100-1109.

Table 1 - Chemical composition, As content and textural classification of soil samples of Ouro Preto, MG

\begin{tabular}{|c|c|c|c|c|c|c|c|c|c|c|c|c|c|c|c|c|}
\hline \multirow[b]{2}{*}{ Sample } & \multicolumn{11}{|c|}{ Chemical Composition } & \multicolumn{4}{|c|}{ Granulometric Composition } & \multirow[b]{2}{*}{$\begin{array}{c}\text { Textural } \\
\text { Classification }\end{array}$} \\
\hline & $\begin{array}{c}\mathrm{SiO}_{2} \\
\%\end{array}$ & $\begin{array}{c}\mathrm{TiO}_{2} \\
\%\end{array}$ & $\begin{array}{c}\mathrm{Al}_{2} \mathrm{O}_{3} \\
\%\end{array}$ & $\begin{array}{c}\mathrm{Fe}_{2} \mathrm{O}_{3} \\
\%\end{array}$ & $\begin{array}{c}\mathrm{CaO} \\
\%\end{array}$ & $\underset{\%}{\mathrm{MgO}}$ & $\underset{\%}{\mathrm{MnO}}$ & $\begin{array}{c}\mathrm{Na}_{2} \mathrm{O} \\
\%\end{array}$ & $\begin{array}{c}\mathrm{K}_{2} \mathrm{O} \\
\%\end{array}$ & $\begin{array}{c}\mathrm{P}_{2} \mathrm{O}_{5} \\
\%\end{array}$ & $\begin{array}{c}\mathrm{As} \\
\mathrm{mg} / \mathrm{kg}\end{array}$ & Clay & Silt & $\begin{array}{l}\text { Fine } \\
\text { Snad }\end{array}$ & Coarse & \\
\hline SOL01 & 57,70 & 0,47 & 14,60 & 17,60 & 0,23 & 0,65 & 0,11 & 0,28 & 2,24 & 0,127 & 660 & 29,62 & 12,45 & 40,33 & 17,6 & Sandy Clay Loam \\
\hline SOL02 & 47,30 & 0,71 & 9,02 & 32,80 & 1,01 & 0,56 & 0,07 & $<0,10$ & 0,9 & 0,166 & 725 & 40,61 & 18,63 & 28,62 & 12,14 & Clay Loam \\
\hline SOL03 & 55,20 & 0,54 & 9,11 & 19,70 & 1,97 & 1,16 & 0,18 & $<0,10$ & 0,98 & 0,404 & 353 & 33,85 & 18,82 & 29,95 & 17,38 & Sandy Clay Loam \\
\hline SOL04 & 76,20 & 0,46 & 6,53 & 11,10 & 0,68 & 0,51 & 0,25 & 0,14 & 1,05 & 0,091 & 46 & 21,65 & 14,08 & 42,76 & 21,51 & Sandy Loam \\
\hline SOL05 & 66,50 & 0,45 & 7,38 & 17,60 & 1,06 & 0,94 & 0,54 & 0,13 & 1,45 & 0,106 & 130 & 24,99 & 11,56 & 38,19 & 25,26 & Sandy Loam \\
\hline SOL06 & 97,90 & 0,03 & 0,47 & 1,50 & 0,04 & 0,11 & 0,03 & $<0,10$ & 0,11 & 0,013 & 6 & 0,58 & 15,56 & 61 & 22,86 & Sand \\
\hline SOL07 & 36,00 & 2,00 & 6,01 & 49,60 & 0,04 & 0,28 & 0,12 & $<0,10$ & 0,42 & 0,149 & 386 & 61,86 & 21,09 & 14,03 & 3,02 & Clay \\
\hline SOL08 & 62,40 & 0,98 & 9,82 & 18,10 & 0,11 & 0,31 & 0,50 & 0,16 & 1,08 & 0,086 & 17 & 31,04 & 13,01 & 36,24 & 19,71 & Sandy Clay Loam \\
\hline SOL09 & 60,70 & 0,76 & 14,40 & 11,60 & 1,48 & 1,16 & 0,05 & 0,20 & 2,17 & 0,068 & 34 & 26,88 & 10,83 & 38,62 & 23,67 & Sandy Loam \\
\hline SOL10 & 24,90 & 0,09 & 1,05 & 70,80 & 0,87 & 0,34 & 0,08 & $<0,10$ & 0,06 & 0,164 & 22 & 66,87 & 19,42 & 9,65 & 4,06 & Clay \\
\hline SOL11 & 29,20 & 0,09 & 3,02 & 54,40 & 2,38 & 1,64 & 0,24 & 0,23 & 0,33 & 0,299 & 610 & 51,87 & 17,23 & 22,42 & 8,48 & Clay \\
\hline SOL12 & 25,30 & 0,03 & 0,94 & 70,70 & 0,10 & 0,28 & 0,10 & 0,21 & 0,17 & 0,191 & 925 & 69,06 & 21,28 & 7,37 & 2,29 & Clay \\
\hline SOL13 & 22,80 & 0,09 & 1,38 & 71,90 & 0,28 & 0,33 & 0,07 & $<0,10$ & 0,04 & 0,321 & 515 & 71,02 & 18,03 & 7,58 & 3,37 & Clay \\
\hline SOL14 & 67,40 & 0,90 & 6,89 & 12,60 & 2,50 & 1,80 & 0,54 & 0,24 & 1,14 & 0,172 & 245 & 19,03 & 12,06 & 46,54 & 22,37 & Sandy Loam \\
\hline SOL15 & 43,00 & 0,09 & 1,77 & 49,50 & 0,12 & 1,12 & 0,19 & $<0,10$ & 0,22 & 0,179 & 910 & 50,67 & 18,88 & 20,23 & 10,22 & Clay \\
\hline SOL16 & 39,70 & 0,83 & 23,00 & 20,90 & 0,20 & 0,51 & 0,11 & 0,25 & 1,45 & 0,228 & 686 & 46,65 & 10,87 & 24,99 & 17,49 & Sandy Clay \\
\hline SOL17 & 61,70 & 0,67 & 14,00 & 12,10 & 1,30 & 0,92 & 0,10 & 0,17 & 2,19 & 0,117 & 61 & 29,26 & 16,00 & 38,44 & 16,3 & Sandy Clay Loam \\
\hline SOL18 & 44,10 & 0,30 & 3,96 & 44,00 & 0,43 & 0,40 & 0,09 & $<0,10$ & 0,52 & 0,220 & 905 & 51,29 & 12,64 & 28,11 & 7,96 & Clay \\
\hline SOL19 & 44,50 & 0,26 & 3,47 & 33,80 & 3,95 & 2,08 & 0,21 & $<0,10$ & 0,43 & 0,165 & 840 & 37,00 & 15,27 & 36,08 & 11,65 & Sandy Clay Loam \\
\hline SOL20 & 28,50 & 0,40 & 4,13 & 58,10 & 0,15 & 0,44 & 0,82 & $<0,10$ & 0,31 & 0,375 & 925 & 57,81 & 11,25 & 24,24 & 6,7 & Clay \\
\hline SOL21 & 62,00 & 0,83 & 12,10 & 14,40 & 0,42 & 0,53 & 0,17 & 0,18 & 1,85 & 0,113 & 186 & 27,55 & 17,73 & 36,75 & 17,97 & Sandy Loam \\
\hline
\end{tabular}


Table 2 - Rotated factor Loadings and Communalities for the correlation matrix of sample data of soil (Varimax Rotation).

\begin{tabular}{lcccc}
\hline Variable & $\mathrm{F} 1$ & $\mathrm{~F} 2$ & $\mathrm{~F} 3$ & Communality \\
\hline $\mathrm{SiO}_{2}$ & 0,979 & 0,086 & $-0,013$ & 0,967 \\
$\mathrm{TiO}_{2}$ & 0,064 & 0,547 & 0,230 & 0,357 \\
$\mathrm{Al}_{2} \mathrm{O}_{3}$ & 0,159 & 0,930 & 0,014 & 0,891 \\
$\mathrm{Fe}_{2} \mathrm{O}_{3}$ & $-0,862$ & $-0,429$ & 0,145 & 0,949 \\
$\mathrm{CaO}$ & 0,074 & $-0,105$ & $-0,856$ & 0,749 \\
$\mathrm{MgO}$ & 0,038 & 0,025 & $-0,913$ & 0,836 \\
$\mathrm{MnO}$ & $-0,009$ & 0,082 & $-0,433$ & 0,194 \\
$\mathrm{Na} 2 \mathrm{O}$ & 0,088 & 0,727 & $-0,169$ & 0,565 \\
$\mathrm{~K}_{2} \mathrm{O}$ & 0,402 & 0,827 & $-0,078$ & 0,851 \\
$\mathrm{P}_{2} \mathrm{O}_{5}$ & $-0,726$ & $-0,087$ & $-0,332$ & 0,645 \\
$\mathrm{As}$ & $-0,690$ & $-0,099$ & $-0,210$ & 0,530 \\
$\mathrm{Clay}$ & $-0,946$ & $-0,173$ & 0,218 & 0,972 \\
$\mathrm{Silt}$ & $-0,351$ & $-0,502$ & 0,367 & 0,510 \\
Fine Sand & 0,915 & 0,151 & $-0,259$ & 0,927 \\
Coarse Sand & 0,850 & 0,389 & $-0,239$ & 0,931 \\
& & & & \\
Variance & 5,4898 & 3,0615 & 2,3232 & 10,8745 \\
\% Var & 0,366 & 0,204 & 0,155 & 0,725 \\
\hline
\end{tabular}

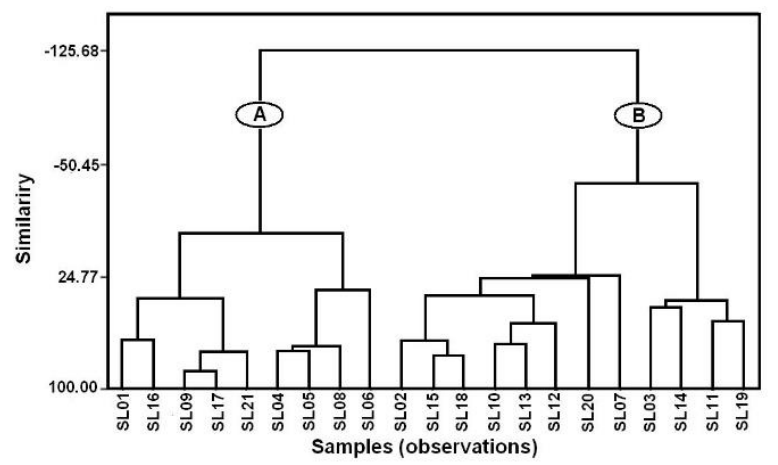

Figure 3 - Results of Cluster Analysis (R-mode) of soil sampling. A - samples in the Southern part of the area; $\mathrm{B}$ - samples in the Northern part of the area.
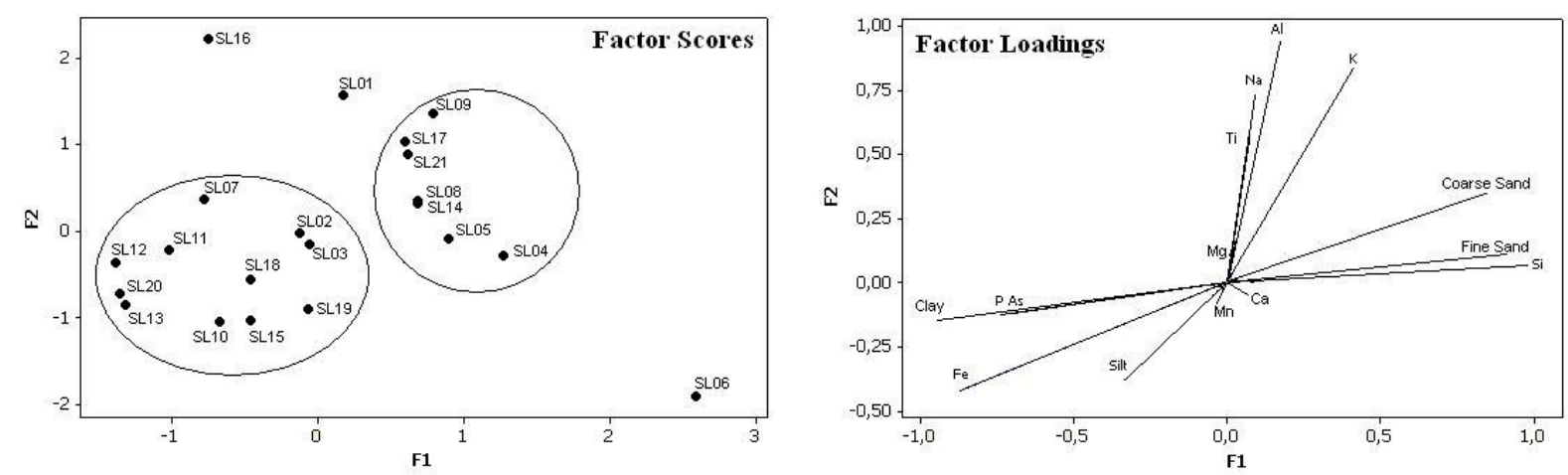

Figure 4 - Plots of score factor (left) and loading factor (right) for the soil samples of Ouro Preto city 
The diagram of scores for factors F1 and F2 (Figure 4) allow the classification of samples in terms of these two factors, which, together, explain $57.0 \%$ of the variance of data and take into consideration the contribution of quartz, goethite and kaolinite (main mineral component of soils). The diagram shows that two groups stand out. The first one (A) constituted by SOL09, SOL17, SOL21, SOL14, SOL08, SOL05 and SOL04 and a second one (B) with samples SOL07, SOL02, SOL03, SOL20, SOL11, SOL12, SOL18, SOL13, SOL15, SOL19 and SOL 10. Samples SOL 06, SOL01 and SOL16 do not fit in any one of the two groups. However taking into consideration the dendrogram of Figure 3, it would be reasonable to consider them as outliers of group A. The location of the samples on the map of the studied area (Figure 1) reveals that group A is located at South of the region, while group B is located at North of the region. Figure 4 presents the loading values of each element for the first two factors. This procedure allows an assessment of the correlation between the variables and the role they play in the characteristics of the sample. This diagram shows 4 groups of variables and their association. a) $\mathrm{Fe}_{2} \mathrm{O}_{3}$, As and $\mathrm{P}_{2} \mathrm{O}_{5}$; clay and silt b) $\mathrm{Na}_{2} \mathrm{O}, \mathrm{K}_{2} \mathrm{O}, \mathrm{Al}_{2} \mathrm{O}_{3}$ and $\mathrm{TiO}_{2}$; c) $\mathrm{SiO}_{2}$, fine and coarse sand d) $\mathrm{MnO}, \mathrm{MgO}$ and $\mathrm{CaO}$. More informative is to compare the diagrams of Figures 3 and 4. Samples of group $\mathrm{B}$ and $\mathrm{Fe}_{2} \mathrm{O}_{3}, \mathrm{As}, \mathrm{P}_{2} \mathrm{O}_{5}$, clay and silt are in the same quadrant showing that the presence of these elements are responsible for the classification of this samples in one group. On the other hand $\mathrm{Na}_{2} \mathrm{O}, \mathrm{K}_{2} \mathrm{O}, \mathrm{Al}_{2} \mathrm{O}_{3}$, $\mathrm{SiO}_{2}$, coarse and fine sand as well as samples of group A are in the same quadrant. Again it is possible to say that these elements and the minerals they represent are responsible for the separation of this group. Sample SOL06 stands out as an outlier of group A (compare with the dendrogram of Figure 3), in the same quadrant of $\mathrm{SiO}_{2}$. This sample is particularly characterized by the presence of quartz. Hence its separation from the remaining samples. Also samples SOL01 and SOL16 may be classified as outliers of group $\mathrm{A}$. These samples are characterized by high content of $\mathrm{Al}_{2} \mathrm{O}_{3}$ and $\mathrm{Fe}_{2} \mathrm{O}_{3}$.
These results shows that As is distributed in the North of the studied region, strongly linked to clay fraction, which, in turn, is characterized by the presence of goethite and talc. The latter mineral is a carrier of As. High As contents have already been reported associated with minerals of the talc type (Moen et al. 2010), which were attributed to their presence in the crystalline structure, characterizing them as possible primary mineral carriers of As. The As (III) may participate in the crystalline structure of the Fe oxides due to the facility of incorporation of this element in this state of oxidation in the crystalline structure of the maghemite and hematite, the main mineral carriers of As in mineralized zones (Walker \& Jamieson 2005). Arsenates coprecipitated with amorphous iron oxides, may be stabilized and crystallized during the transformation of amorphous oxides in crystalline oxides (Ford 2002).

\section{Conclusions}

In the city of Ouro Preto, the soils of the neighborhoods Alto da Cruz, Padre Faria, Piedade, and Antônio Dias present high total As contents that widely go beyond the maximum admissible value for any type of use.

The soil samples analyzed presented relatively similar textural organization and chemical and mineral composition. In mineralogical analyses were identified silicates whose predominance is of quartz, muscovite and kaolinite. In addition, a variety of iron and aluminum oxides and/or oxides-hydroxides stood out, represented by goethite, hematite and gibbsite.

Autigenic or secondary minerals of As were not found in the soils studied. The absence of these minerals in the soils analyzed result in a large quantity of As retained in the crystalline and noncrystalline (amorphous materials) iron oxides formed during the meteorization processes of the substrate rocks.

Finally, As is distributed in the North of the studied region, strongly linked to clay fraction, characterized by the 
presence of goethite and talc, which are the carriers of As.

\section{Acknowledgments}

The present work was possible thanks to the logistic support of the Ouro Preto Bourough Council. The authors would also like to thank the Mineralogy Laboratory of the Universidade Federal de Viçosa Soil Department. The first author thanks to CAPES-MEC (Coordenadoria de Aperfeiçoamento do Pessoal do Ensino Superior - Brazilian Ministry of Education) for his Ph.D. scholarship.

\section{References}

Alkmim, F. F. Marshak S., 1998. Transamazonian orogeny in the southern São Francisco Craton Region, Minas Gerais, Brazil: evidence for paleoproterozoic collision and collapse in the Quadrilátero Ferrífero. Precambrian Research 90, 29-58.

Alloway, B. J., 1990. The origin of heavy metals in soils. In: Alloway B. J. (Ed.) Heavy metals in soils. John Wiley \& Sons, New York.

Andrade, L. N., Leite, M. G. P., Barcellar, L. A. P., 2000. Influência geológica em assinaturas químicas das águas e solos do Parque do Itacolomi, Minas Gerais. Revista Escola de Minas 62,147-154.

Borba, R. P., 2002. Arsênio em ambiente superficial: processos geoquímicos naturais e antropogênicos em uma área de mineração aurífera. Ph. D. Thesis. Campinas: Instituto de Geociências, Universidade Estadual de Campinas UNICAMP.

Coelho, I. G. D., 1994. Clima. In: Alvim PRJ (Coord) Desenvolvimento Ambiental de Ouro Preto-Microbacia do Ribeirão do Funil, MG. CETEC/IGA-SAE/PR, Belo Horizonte.

Curi, N., Franzmeier D. P., 1987. Effect of parent rocks on chemical and mineralogical properties of some oxisols in Brazil. Soil Science Society of America Journal 51, 153-158.

Dorr II, J. V. N., 1969. Phisiographic, stratigraphic and structural development of the QF, Brazil. Profisional Paper 641A. Washington, DNPM/USGS.

Dorr II, J. V. N., Gair, J. E., Pomerene, J. G., Rynearson, G. A., 1957. Revisão da estratigrafia pré-cambriana do Quadrilátero Ferrífero. DNPM-DFPM, Rio de Janeiro.

Eleutério, L., 1997. Diagnóstico da situação ambiental da cabeceira da bacia do rio Doce, no âmbito das contaminações por metais pesados em sedimentos de fundo. Dissertação (Mestrado). Ouro Preto: Departamento de Geologia, Escola de Minas, Universidade Federal de Ouro Preto - UFOP.

Everitt, B. S., Landau, S., Leese M., Stahl D.. 2011. Cluster Analysis (5th Ed). Chichester: Wiley - UK.

Ferreira, A. F., Lazarin. H. A., 1993. Caracterização litoestrutural e geomorfológica da região do Pico do Itacolomi, Monografia de Graduação. Ouro Preto: Departamento de Geologia, Universidade Federal de Ouro Preto UFOP.

Ford, R. G., 2002. Rates of hydrous ferric oxide crystallization and the influence on coprecipitated arsenate. Environmental Science \& Technology 36(2), 459- 463.

Gee, G.W., Bauder, J.W., 1986. Particle-size analysis. In: Klute, A. (Ed.) Methods of soil analysis. Part 1: Physical and Mineralogical Methods. Soil Science Society of America, Madison 383-412.

Gonçalves, J. A. C., 2011. A contaminação natural por arsênio em solos e águas subterrâneas na área urbana de Ouro Preto (MG). Tese (Doutorado). Departamento de Geologia, Universidade Federal de Ouro Preto - UFOP.

Gonçalves, J. A. C., Lena, J. C., Paiva, J. F., Nalini Jr., H. A., Pereira, J. C., 2007. Arsenic in the groundwater of Ouro Preto (Brazil): Its temporal behavior as influenced by hydric regime and hydrology. Environmental Geology 53, 785-793.

IGA. Instituto de Geociências Aplicadas, 1995. Desenvolvimento Ambiental de Ouro Preto - Microbacia do Ribeirão do Funil. Belo Horizonte.

Kabata-Pendias, A., 2004. Soil-plant Transfer of Trace Elements - an 
Environmental Issue. Geoderma 122, 143-149.

Ladeira, E. A., 1980. Metallogenesis of Gold at the Morro Velho Mine, and in Nova Lima District, Quadrilátero Ferrífero, Minas Gerais, Brazil. PhD Thesis. London: University of Western Ontario

Licht, O. A. B., Plawiak, R. A. B., 2005.Levantamento Geoquímico Multielementar do Estado do Paraná: Fase 2 - Horizonte B dos Solos. Relatório Final do Projeto. Curitiba, MINEROPAR, 2 .

Manly B. J. F., 2004. Multivariate Statistical Methods: A Primer. Chapman \& Hall/CRC. 3rd Ed.

Marques, J. J. G. S. M., 2000. Trace element distributions in Brazilian Cerrado at the landscape and micrometer scales. Tese (Doutorado). West Lafayette: Purdue University.

Marshak, S., Alkmim F. F., 1989. Proterozoic extension/contraction

Geology 43, 725-730. tectonics of the São Francisco Craton and adjacent regions, Minas Gerais, Brazil: A kinematic model relating Quadrilátero Ferrífero, São Francisco Basin and Cordilheira do Espinhaço. Tectonics 8, 555-571.

Matschullat, J., Borba, R. P., Deschamps, E., Figueiredo, B., Gabrio, T., 2000. Human and environmental contamination in the Iron Quadrangle, Brazil. Applied Geochemistry 15, 181-190.

Moen, J., Ryan, P. C., Jon, K., 2010. Analysis of arsenic speciation in ultramafic rocks by sequential chemical extraction: implications for Taconian fluid source and modern aquifer contamination. Geological Society of America Abstracts with Programs, 42.

Pimentel, H.S., Lena, J.C., Nalini, Jr H. A., 2003. Studies of water quality in the Ouro Preto region, Minas Gerais, Brazil: The release of arsenic to the hydrological system. Environmental 